\title{
The Dynamics of Water Quality Soft-Shelled Crab Aquaculture in Pemalang Regency, Middle Java, Indonesia
}

\author{
Muhamad Agus ${ }^{1}$, Johanes $\mathbf{H}^{2}$, YS Darmanto ${ }^{3}$, S. Budi Prayitno ${ }^{4}$ \\ ${ }^{1}$ Department of Aquaculture Pekalongan University-Indonesia \\ ${ }^{1}$ Doctoral Candidate, Department of Coastal Resources Management Diponegoro University- Indonesia \\ 2, 3, 4 Department of Coastal Resources Management Diponegoro University-Indonesia
}

\begin{abstract}
The purpose of this study to determine the dynamics of water quality soft-shelled crab aquaculture in Pemalang Regency in 2011-2013. The results showed that the water quality conditions are not suitable for media live crabs. This is demonstrated by the increased organic matter from 85.68 - $119.93 \mathrm{mg} / \mathrm{l}$, dissolved carbon dioxide range of 4.8 - $17.9 \mathrm{mg} / \mathrm{l}$, phytoplankton density increased from $33.8 * 10^{4}$ to $39.3 * 10^{4}$ cells / cc, dissolved oxigen range $2.5-5.4 \mathrm{mg} / \mathrm{l}$, pH 5.6 - 6.8, salinity 22-28 ppt (median range $24-26 \mathrm{ppt}$ ), and temperature 23 - 32 degrees Celsius (median range $26-29^{\circ} \mathrm{C}$ ). The production decreased from $1340-1190 \mathrm{~kg} / 0,35 \mathrm{ha}$.
\end{abstract}

Keyword: Aquaculture, Soft-Shelled Crab, Water Quality.

\section{Introduction}

The Soft-shelled crabs are soft-shell crab that has undergone a change of skin (molting). Pemalang Regency is a softshelled crab aquaculture centers in Middle Java of Indonesia, with production of $2500 \mathrm{~kg} / 0$,35ha in 2005. The production of soft-shelled crabs decreased $1810 \mathrm{~kg} / 0.35$ ha in 2011, and production only reached $1180 \mathrm{~kg} / 0.35$ ha in 2013. The management of soft-shelled crab aquaculture in Pemalang Regency conducted semi-intensive, Kroyo stocking densities, the young crabs that are used as seed, reached $4-5 \mathrm{crab} / \mathrm{m}^{3}$. Trash fish feed by $10 \%$ / BB / hr. Water circulation system is gravity ranging from $13-16 \%$ per day, let in and let out ponds using 4 pieces of PVC pipe 8 ', the mean volume of $3500 \mathrm{~m}^{3}$ pond. Agus (2008) states, Kroyo ideal stocking densities up to 3 ekor.m-3, it is based on the ability carryng capacity of ponds in the Pemalang Regency. The results of research Agus (2008; 2010; 2013) that the water quality aquaculture of softshelled crabs in Pemalang Regency in 2005 in the range of feasible for farming crabs are DO (4.6 - $5.1 \mathrm{mg} / \mathrm{l}), \mathrm{CO}_{2}(7.6$ - $8.2 \mathrm{mg} / \mathrm{l})$, $\mathrm{pH}$ (7.3 - 7.9), Organic Matter (9.83 mg / l), $\mathrm{NO}_{3}(1.8 \mathrm{mg} / \mathrm{l})$, total phosphorus $(0.05 \mathrm{mg} / \mathrm{l})$, the density of phytoplankton $\left(7.1 * 10^{4}-8.1 * 10^{4}\right.$ cells / cc). The growth and survival of the crab is strongly influenced by the physiological and metabolic optimum, while water quality conditions as the medium of live crab is very influential on the physiological and metabolic (Huberman, 2000; Erner et al, 2001; Bocking et al, 2002; Sorta and Yuwono 2005; Karim, 2006; Mykles, et al, 2010). The purpose of this study to determine the relationship dynamics of water quality softshelled crab aquaculture to the decline in production.

\section{Materials and Methods}

\section{Study Area}

This study was conducted in 24 ponds, which are used for the aquaculture of soft-shelled crabs in the village Mojo Ulujami in Pemalang Regency as the centra of soft-shelled crab aquaculture in middle Java of Indonesia

\section{Water Quality and Production Yield Analysis}

The Present investigation is made between January 2011 and January 2013. The water quality data and production results were analyzed descriptively while relations were analyzed with regression correlation. The analyzable in some parameters for water quality that is organic meters, dissolved carbon dioxide $\left(\mathrm{CO}_{2}\right)$, phytoplankton density, dissolved oxigen, $\mathrm{pH}$, salinity and temperature. The water quality samples were collected from soft-shelled crab pond aquaculture by Spectrophotometer for organic meters, dessolved carbon dioxide $\left(\mathrm{CO}_{2}\right)$, Sedgwick-rafter for cell counting phytoplankton, walklab digital oxygen meter for dissolved oxygen, $\mathrm{pH}$ digital meter for water $\mathrm{pH}$, refractometer for water salinity and thermometer (Hg) for temperature. The production results is calculated based on the total weight of the molting crabs.

\section{Result and Discussion}

The condition of the water quality in aquaculture ponds softshelled crabs are not suitable for media live crabs. The condition of the water quality in aquaculture ponds softshelled crabs are not suitable for media live crabs. This is demonstrated by the increased organic matter from 85.68 $119.93 \mathrm{mg} / \mathrm{l}$, dissolved carbon dioxide range of 4.8 - 17.9 $\mathrm{mg} / \mathrm{l}$, phytoplankton density increased from $33.8 * 10^{4}$ to $39.3 * 10^{4}$ cells / cc, dissolved oxigen range $2.5-5.4 \mathrm{mg} / \mathrm{l}$, pH 5.6 - 6.8, salinity 22-28 ppt (median range 24-26ppt), and temperature 23 - 32 degrees Celsius (median range $26-29{ }^{\circ} \mathrm{C}$ ). Production results decreased from 1340 - $1190 \mathrm{~kg} /$ 0,35 ha. The organic material in the pond increases with the softshelled crab aquaculture activities. The linkage relationships soft-shelled crab aquaculture period to increase positive linear patterned organic material $\left(\mathrm{Y}=1,387 \mathrm{X}-16.58 \mathrm{R}^{2}=\right.$ 0.83). The increasing the organic matter due to the accumulation of food remains and feces of crabs were cultivated. Stocking density crab $4-5 \mathrm{crab} / \mathrm{m} 3$ belonging to exceed the ideal stocking density ranging from $2-3$ tail / m2. (Agus, 2008). The content of organic material in aquaculture depends on the stocking density, efficiency of feed 


\section{International Journal of Science and Research (IJSR) \\ ISSN (Online): 2319-7064 \\ Index Copernicus Value (2013): 6.14 | Impact Factor (2014): 5.611}

utilization, and the amount of water circulation daily. The Kultivan high stocking density followed by feeding high anyway, so that feces and waste feed will also increase. Minimal water circulation conditions resulted in an imbalance of water quality, especially the growing organic material impact on kultivan stress to cause a decrease in the efficiency of feed utilization. The organic materials are ideal pond waters range in 20-40 mg / l. Otherwise overly fertile waters when the organic matter content of $>75 \mathrm{mg} / \mathrm{l}$. (Bardach et al, 1973; Zonneveld, 1991; Effendi, 2004; Bulanin and Ronal, 2005; Agus, 2005; 2008; 2009; 2013; 2014). Circulation of water with a range of 13.6 to $16.1 \%$ have not been able to degrade organic matter, so that the organic material in the water in the range of 85.68 - 119.93 $\mathrm{mg} / \mathrm{l}$. This value has been exceeded the threshold for eligibility.

The density of phytoplankton in the pond waters shelled crab aquaculture reached $33.8 * 10^{4}$ to $39.3 * 10^{4}$ cells / cc. Phytoplankton in the pond waters ideal range between $5 * 10^{4}$ $-10 * 10^{4}$ cells / cc, the range has no impact on fluctuations in dissolved oxygen which is quite wide, but the density of phytoplankton> 20x104 cell / cc lead to fluctuating oxygen is very wide, even that range often cause of death in kultivan because oxygen at night in critical condition. The high growth of phytoplankton is caused by an increase in organic material that produces nutrients for phytoplankton growth. The existence of phytoplankton in the waters is affecting the concentration of dissolved oxygen and dissolved $\mathrm{CO}_{2}$, so that there is a relationship between these parameters causalistik, photosynthesis by phytoplankton will increase and decrease the oxygen content of $\mathrm{CO}_{2}$ in the water. (Boyd, 1992; Viyard, 1999; Effendi, 2003; Marsambuana et al, 2008).

High density of phytoplankton causing quite wide fluctuations in dissolved $\mathrm{CO}_{2}$. Photosynthesis during the day led to the use of $\mathrm{CO}_{2}$ dissolved in the pond water so that dissolved $\mathrm{CO}_{2}$ decreases to $4.8 \mathrm{mg} / \mathrm{l}$, and in the evening dissolved $\mathrm{CO}_{2}$ production from the rest of the metabolism, respiration, and penguaraian organic materials increased to $17.9 \mathrm{mg} / \mathrm{l}$. The ideal $\mathrm{CO}_{2}$ dissolved in the pond waters between $5-15 \mathrm{mg} / \mathrm{l}$. Dissolved $\mathrm{CO}_{2}$ reaches $20-60 \mathrm{mg} / \mathrm{l}$ is not a point of lethal concentration in crab cultivation, but it is a compound for crab in taking $\mathrm{O}_{2}$ dissolved through the gills. (Agus, 2015). The presence of $\mathrm{CO}_{2}$ dissolved in water can be an indicator of the amount of dissolved $\mathrm{O}_{2}$ and $\mathrm{pH}$, it is because the amount of $\mathrm{CO}_{2}$ in the water is always inversely proportional to the amount of dissolved $\mathrm{O}_{2}$ and $\mathrm{pH}$ value (Alert and Symmetry, 1984; Boyd, 1992; Effendi, 2003; Avnimelech, 2004).

The dissolved oxygen is one of the important parameters in the soft-shelled crab aquaculture activities in ponds. The presence of oxygen in the water is very important in relation to a variety of aquatic biological chemical processes. Oxygen is required in the process of oxidation of various chemical compounds and respiration of aquatic organisms (Dahuri, et al., 2004). Oxygen is needed in the body of the crab to feed the combustion of which produces energy for activity, the process of osmoregulation, growth, moulting, and reproduction. (Bardach et al, 1973; Zonneveld et al, 1991). Phytoplankton photosynthesis during the day can help supply the dissolved oxygen up to $5.4 \mathrm{mg} / \mathrm{l}$, so that the physiological and metabolic activity of crab met. Molting crab can perfectly when energy sufficiency and dissolved oxygen of at least $4 \mathrm{mg} / \mathrm{l}$. (Karim, 2006). Increased organic matter, phytoplankton, dissolved $\mathrm{CO} 2$, and the high density of the crab population led to the use of oxygen to the fullest until the dissolved oxygen in the range of $2.5 \mathrm{mg} / \mathrm{l}$.

The $\mathrm{pH}$ value tended to decline with soft-shelled crab aquaculture activities in ponds, the $\mathrm{pH}$ value in the range of 5.6-6.8. The magnitude of the $\mathrm{pH}$ value indicates that the pond water aquaculture soft-shelled crabs are dominated $\mathrm{NH} 3$ than $\mathrm{NH}_{4}$, high in organic matter and dissolved $\mathrm{CO}_{2}$ concentration also affects the $\mathrm{pH}$ value decreasing, it is a very resulted in increased respiratory activity so that the dissolved oxygen will be a lot of unutilized. Low dissolved oxygen causes a decrease in appetite, and increased mortality crab. Pond $\mathrm{pH}$ value of less than 6 can cause death on the crab. $\mathrm{pH}$ in acidic conditions contributed to the increased activity of breathing and decreased appetite, $\mathrm{pH}$ on the acidic conditions caused damage to gill tissue (hyperplasia branchia), and increase the concentration of toxic gas (H2S). (Bowman's Lannan, 1995; Boyd et al, 2002; Williams, 2003; Avnimelech, et al, 2004).

The salinity in aquatic ecosystems act as masking factor composed of dissolved ions which include sodium, potassium, calcium, magnesium, chloride, sulfate and salinity bicarbonat.Peran in the aquacultureof soft-shelled crab is very important, because it affects the process osmoregulasi, metabolism, phase molting and growth. Optimal salinity (24$28 \mathrm{ppt}$ ) and supported by the dissolved oxygen $>4 \mathrm{mg} / \mathrm{l}$ greatly assist the smooth phase of molting maintain osmoregulation processes, metabolism and growth. (Erner et al, 2001; Bocking et al 2002; Sorta and Yuwono, 2005; Karim, 2007; Fujaya, 2008). The Salinity of pond water in the aquacultureof soft-shelled crabs ranges from 22-28 ppt, (median range 24-26 ppt), so that the range of the stretcher in the normal range for crabs in the hold of physiological activity (osmoregulasi and molting) and metabolic activity, but because of dissolved oxygen which is only around $2.5 \mathrm{mg}$ $/ \mathrm{l}$ and a high concentration of $\mathrm{CO}_{2}$ dissolved in water is in the range of $17.9 \mathrm{mg} / \mathrm{l}$, and the condition is relatively close to a $\mathrm{pH}$ value of acid, have an impact on the crab's ability to carry out activities of each phase of molting into abnormal, in addition to the conditions it also causes metabolic processes feed on crabs are also not optimal, it as a cause of declining production. Optimal salinity for molting crabs ranged from 24 ppt - 28 ppt nevertheless dissolved oxygen is also a limiting factor in the growth and molting crabs, it is because the dissolved oxygen used for respiration not only alone but also used for other physiological processes. (Sorta and Yuwono (2005); Karim (2007); Agus (2008).

The temperatur in waters act as a controlling factor, all the processes in the aquatic ecosystem balance is controlled by the temperature. Water temperature orgnisme affect physiological processes such as respiration, metabolism, feed intake, growth, behavior, reproduction, detoxification and bioaccumulation speed and survival. (Boyd, 1992; Effendi, 2003; Cholik, 2005; Fuad, 2005). Temperatures in the waters of soft-shelled crab aquaculture in ponds range from 23 $32^{\circ} \mathrm{C}$. Temperatures during the day ranging from $27^{\circ} \mathrm{C}$ to 32 ${ }^{\circ} \mathrm{C}$, while during the night of 24 to $26^{\circ} \mathrm{C}$. Temperature range 


\section{International Journal of Science and Research (IJSR) \\ ISSN (Online): 2319-7064 \\ Index Copernicus Value (2013): 6.14 | Impact Factor (2014): 5.611}

is feasible for the life of the crab, physiology and metabolic activity will run normally when the conditions of $\mathrm{pH}, \mathrm{CO}_{2}$, dissolved oxygen, salinity and optimal condition parameters. Crabs are under stress and loss of appetite at temperatures $<18{ }^{\circ} \mathrm{C}$ and $>32{ }^{\circ} \mathrm{C}$. (Cholik, 2005).

The results of the production in this study is defined as the weight of the final result that has been molting crab biomass. Molting is a continuous process and a central place in the life of crab. crab growth will not happen without their molting events. Enducitis steroid hormone stimulation is for molting. Crab molting process requires high energy. (Erner et al, 2001; Bocking et al, 2002; Gunamalai et al, 2003; Fujaya, 2008). Survival, crab molting and growth are influenced by physiological and metabolic processes are optimized, while the dynamics of the water quality affects the metabolic and physiological processes including the formation of molting hormone. The production of soft-shelled crabs in the pond aquaculture has decreased from 1340 into $1190 \mathrm{~kg} / 0.35$ ha, this result is far below production in 2005 reaching 2400 to $2500 \mathrm{~kg} / 0.35 \mathrm{ha}$. The decline in production is due to the condition of the water quality is not optimal to support molting. crab looks dead if it fails molting. acidic $\mathrm{pH}$ conditions (5.6), $\mathrm{CO}_{2}$ dissolved $17.9 \mathrm{mg} / \mathrm{l}$ and the dissolved oxygen in the critical value of $2.5 \mathrm{mg} / \mathrm{l}$, is the cause of failure of molting crabs. Failed molting crabs as experienced by physiological and metabolic processes are not perfect. The $\mathrm{pH}$ value of 5.6 had an effect on the increase in the crab respiration, other things look red gill tissue (damaged). Dissolved $\mathrm{CO}_{2}$ reaching $17.9 \mathrm{mg} / \mathrm{l}$ is already causing a decrease in dissolved oxygen exchange in the gills, so the need dissolved oxygen to ecophysiological processes are not optimal, it is exacerbated by the dissolved oxygen in the water is only about $2.5 \mathrm{mg} / \mathrm{l}$.

\section{Conclusion}

The water quality in aquaculture ponds soft-shelled crabs in Pemalang Regency already in conditions unfit for life crabs as seen from the high organic matter reaching $119.93 \mathrm{mg} / \mathrm{l}$, dissolved carbon dioxide range of $17.9 \mathrm{mg} / \mathrm{l}$, phytoplankton density increased from $39.3 * 10^{4}$ cells / cc, dissolved oxigen range $2.5 \mathrm{mg} / \mathrm{l}, \mathrm{pH} \mathrm{5.6}$, and therefore contributes to a decrease in production from 1340 into $1190 \mathrm{~kg} /$ 0.35ha. This value is below the production of 2005 to $2500 \mathrm{~kg} / 0.35$ ha.

\section{References}

[1] Agus M. 2008. Analisis Carryng Capacity Tambak Budidaya Kepiting Kulit Lunak (Kepiting soka) di Kabupaten Pemalang-Jawa Tengah. Laporan Tesis Pasca Sarjana Magister Manajemen Sumberdaya Pantai Universitas Diponegoro. Semarang.

[2] --------- 2013. The Cause Faktor Of Over Carryng Capacity In Soka Crab Pond At Pemalang Regency Crntral Java. Makalah Of International Seminar "Blue Economy In The Pacific RIM In 21st Century". University Of Abdurachman Saleh (UNARS) SitubondoIndonesia. April 26-27, 2013.
[3] ---------- 2014. The Influence Of Dencity and Water Circulation Difference To Total Phospor (TP) and Soka Crab Production Yield. Proceeding Of International Seminar On Marine and Fisheries "Blue Economy Concept In Marine and Fisheries Industry. University Of Pancasakti Tegal - Indonesia. : 152 - 161.

[4] Alets G, Sri Simetri S. 1984. Metode Penelitian Air. Usaha Nasional. Surabaya. Indonesia

[5] Avnimelech,Y., Ritvo, dan G.,Kochva. 2004. evaluating the active redox and organik fractions in pond bottom soils : EOM, eassily oxidized material. Aquaculture 233, 283-292

[6] Bardach JE, J.H.Ryther, dan W.O Larney. 1973. Aquaculture the Farming and Husbandry Of Fresh Water and Marine Organisme.Wiley-Interscience. Adivision of John Wiley \&Sons, Inc. New York

[7] Bocking D, Dircksen H, Keller R. 2002. The Crustacean neuropeptide of the CHH/MIH/GIH Family : Structures and biological activities. The Crustacean nervous sistim. New York : Spinger ; 84-97

[8] Boyd, C.E. 1992. Water Quality Managenent For Pons Fish Culture. Development in Aquaculture and Fisheries Science. Department of Fisheries and allied Aquacultures. Agriculture Experimental Station. Auburn University Alabama USA.

[9] ---------, 2002. Pond Soil Characteristics and Dynamics Of Soil Organik Matter and Nutrients. In : K. McElwee, K.Lewis, M. Nidiffer, and P Buitrago (Edition), Ninetenth Annual Technical Report. Pond Dynamics/Aquaculture CRSP, Oregon State University, Corvallis, Oregon.

[10] Choliq F, 2005. Review of Mud Crab Culture Research in Indonesia. Central Research Institut For Fisheries (310 CRA) : 21-28

[11] Erner S.C, Sharon A.C dan Eva P.M. 2001. Hormon In Crustaces Life. Referring to Proceeding of The International Symphosium. "Ontogonic Strategy of Invertebrata" Hold by Integratif of Biologi Society From Chicago Illinois. January 3-7, 2001 : 19-27

[12] Gunamalai V, R Kirubagaran, dan T. Subramoniam. 2003. Sequesration of Edisteroid Hormone into the Mole Crab. Currents Science. 85 (4) : 493 - 496

[13] Huberman A. (2000). Shrimp Endocrinologi. A review Aquaculture 19_2000 : 191-208

[14] Karim M.Y. 2007. Pengaruh Osmotik Pada Berbagai Tingkat Salinitas Media Terhadap Vitalitas Kepiting Bakau (Scylla olivacea) Betina. Jurnal Protein. 14 (1) : 65-72

[15] Marsambuana Andi Pirzan dan Petrus R.P.M. 2008. Hubungan Keragaman Fitoplankton dengan Kualitas Air di Pulau Bauluang, Kabupaten Takalar, Sulawesi Selatan. Jurnal Ilmiah Biodiversitas 9 (3) : 217 - 221

[16] Mykles D.L, M.E Adams, G.Gade, A.B lange, H.G Marco, and I.Orchard. 2010. Neuropeptide in Insects and Crustacean. Fisiological and Biocemical Zoology 83 (5) : 836-846

[17] Viyard, W. C. 1999. Diatom of Nort America. 1st Edition. Mad River Press Eureka. California.

[18]William, A. W., 2003. Aquaculture Site Selection. Kentucky State University Coorporative Extention Program. Princeton. 


\section{International Journal of Science and Research (IJSR) \\ ISSN (Online): 2319-7064}

Index Copernicus Value (2013): 6.14 | Impact Factor (2014): 5.611

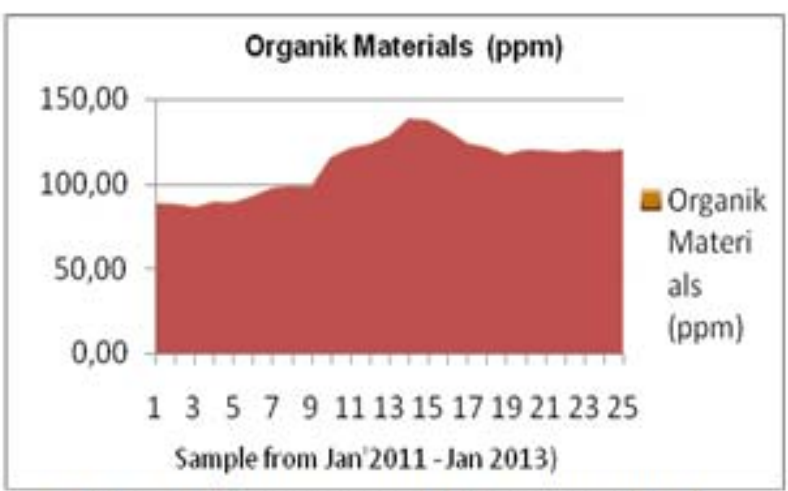

Figure 1: Organic materials dinamic in Pond

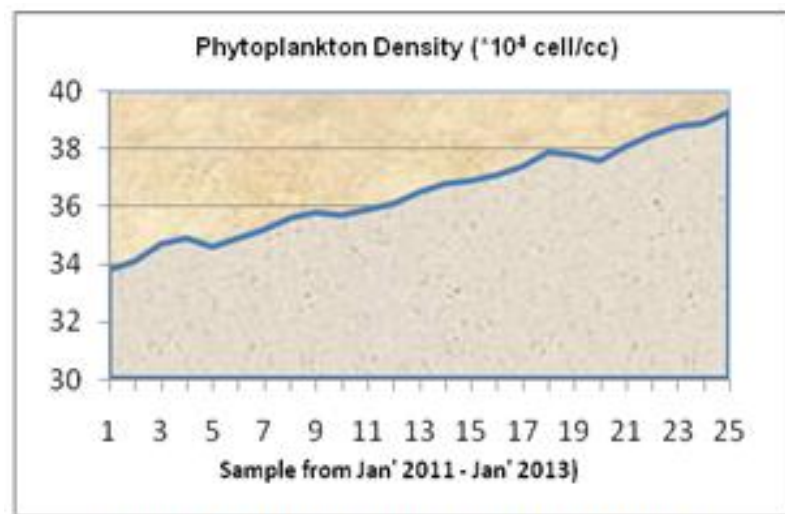

Figure 3: Phytoplankton density in pond

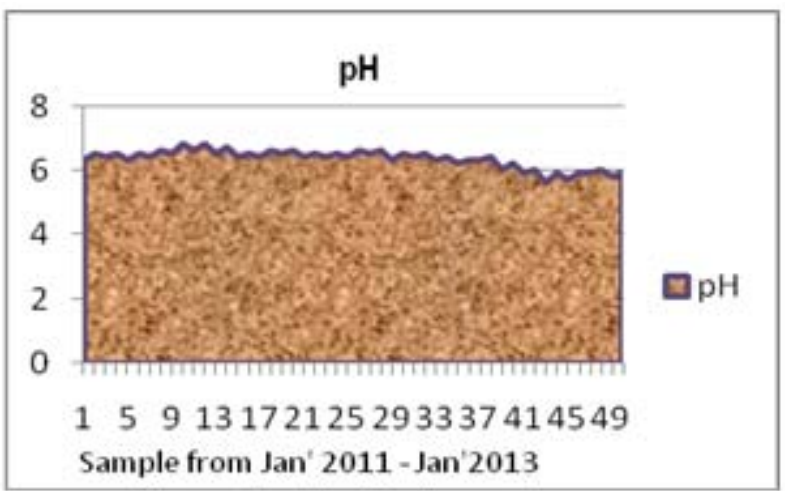

Figure 5: $\mathrm{pH}$ value in pond

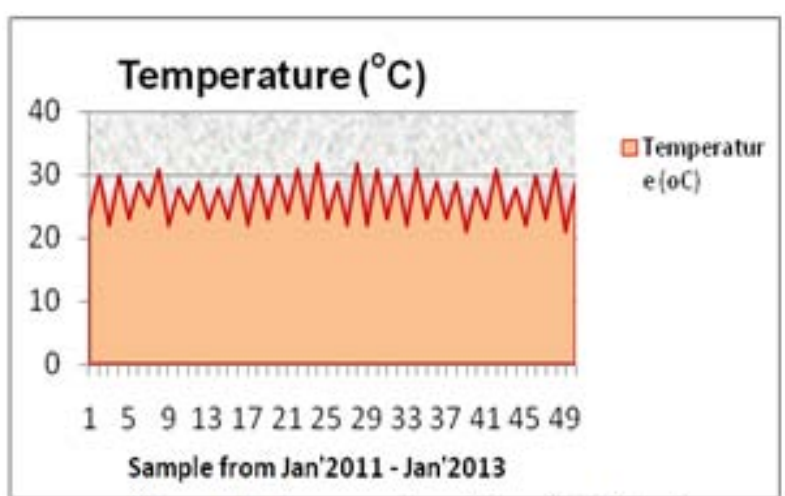

Figure 7: Temperature dinamic in Pond

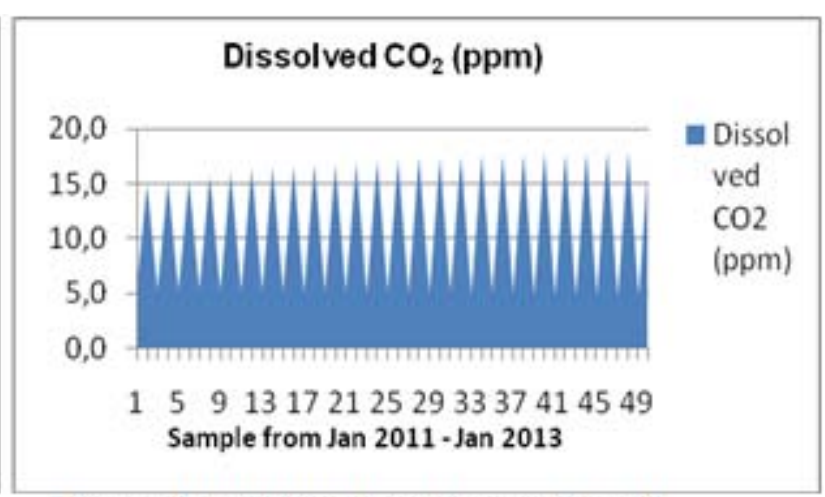

Figure 2: Dissolved $\mathrm{CO}_{2}$ dinamic in pond

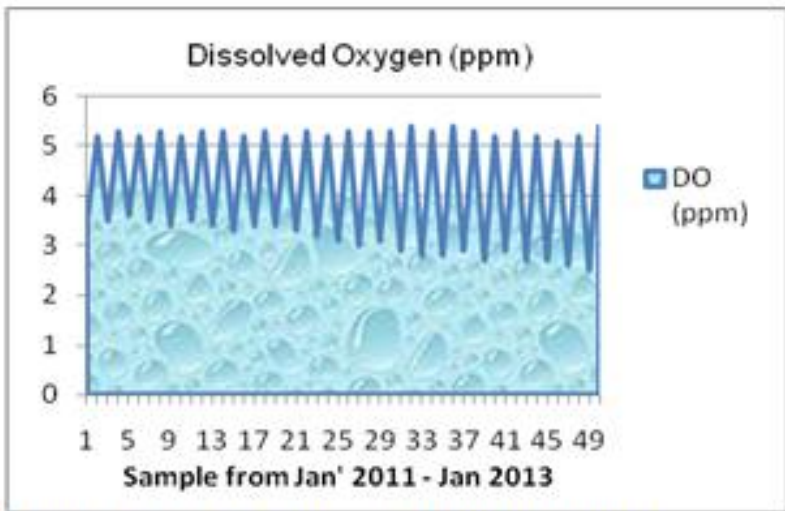

Figure 4: Dissolved oxygen dinamic in pond

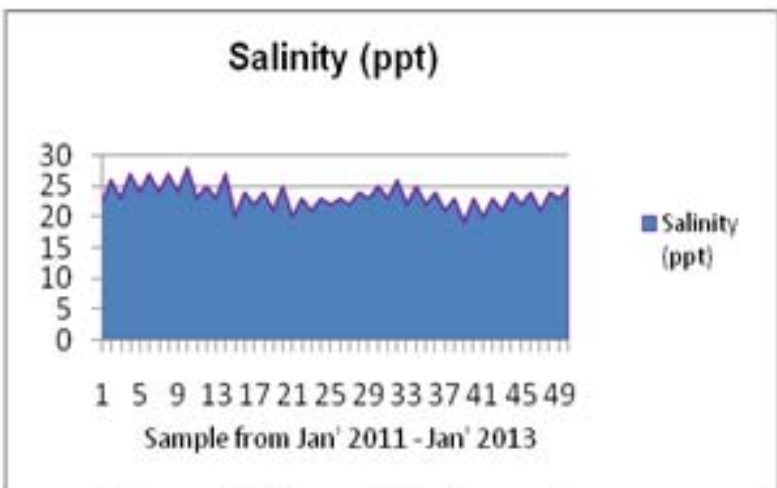

Figure 6: Water salinity in pond

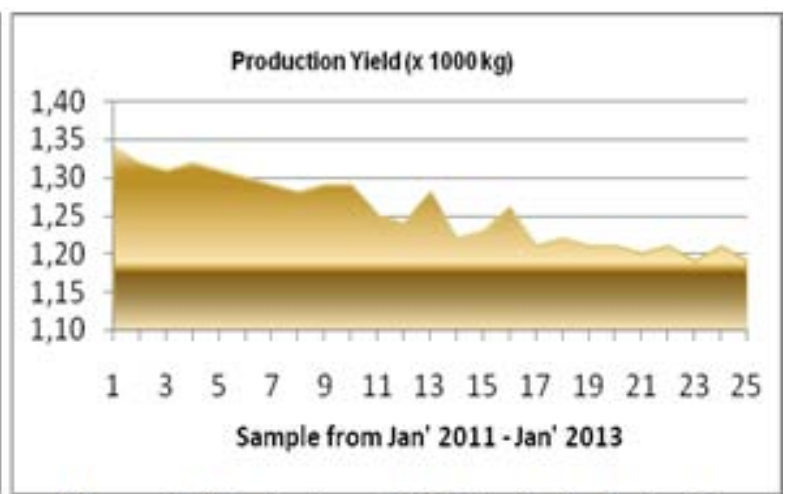

Figure 8: Production yield of soft-shelled crab 